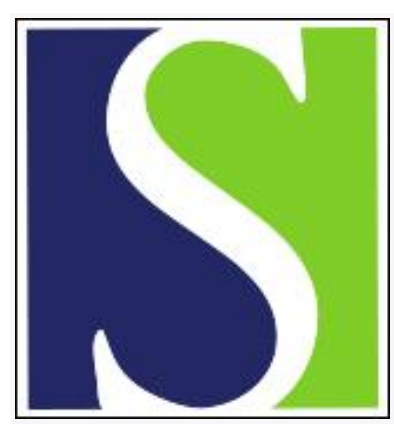

Scand J Work Environ Health 1983;9(5):449-450

https://doi.org/10.5271/sjweh.2390

Issue date: Oct 1983

\title{
Cutting oils and bladder cancer.
}

by Vineis $P$, Di Prima S

This article in PubMed: www.ncbi.nlm.nih.gov/pubmed/6673102

\section{(c) (1)}




\section{Cutting oils and bladder cancer}

Metal machinists, and particularly turners, are heavily exposed to cutting oils. Early case series (11) and recent epidemiologic studies $(9,10)$ have shown marked excess risks of scrotal cancer among turners and other machinists. We wish to suggest in this letter that machinists might have an excess risk of bladder cancer as well.

Case-referent studies conducted in the United States, England, Canada, Finland, and Italy have been reported showing relative risks ranging from 1.5 to 5.0 for machinists and/or engineering fitters and engineers. Relative risks were 4.0 (based on four cases versus one expected in the United States) (5), 4.8 (based on 13 cases exposed for 20 or more years and 4 surgical referents in England) (1), 2.7 (in Canada, $95 \%$ confidence limits 1.1-7.6) (7), 5.0 (based on five cases and one referent in discordant pairs in Finland) (12), 1.5 (in England, $95 \%$ confidence limits 1.2-1.8, the predominant category being represented by turners) (2), 2.7 [based on 11 cases (turners only) and 4 referents in discordant pairs in Italy; all started work before 1945] (13). Although these studies did not control for smoking habits, the consistency of the findings is remarkable.

In other available case-referent studies $(3,14)$ occupational categories do not permit the identification of machinists.

In addition a descriptive study of bladder cancer mortality by local authority areas in England has revealed higher mortality rates in areas where a concentration of precision-engineering industries is present (6).

Cohort studies on metalworkers exposed to oil mist are only partially informative since the numbers are small and bladder cancer is not reported separately for machinists. In the largest investigation six bladder cancer deaths occurred versus five expected (4). In another study three bladder cancers were found among 11,040 person-years at risk (a finding suggesting increased risk) (9). In a study on workers exposed to an antirust oil two cases were found among 78 females (an occurrence much higher than expected) (8).

Aromatic amines are and have been used as antioxidants in cutting oils (15). This use gives biological plausibility to the presented hypothesis, which however requires confirmation.

\section{References}

1. Anthony HM, Thomas GM. Tumours of the urinary bladder: An analysis of the occupations of 1,030 patients in Leeds, England. $J$ natl cancer inst 45 (1970) 879-895.

2. Cartwright $R$. Occupational bladder cancer and cigarette smoking in West Yorkshire. Scand $j$ work environ health 8 (1982): suppl $1,79-82$.

3. Cole P, Hoover R, Friedell GH. Occupation and cancer of the lower urinary tract. Cancer 29 (1972) 1250-1260.

4. Decouflé P. Further analysis of cancer mortality patterns among workers exposed to cutting oil mist. J natl cancer inst 61 (1978) $1025-1030$.

5. Dunham LJ, Robson AS, Stewart HL, Frank AS, Young JL. Rates, interview, and pathology study of cancer of the urinary bladder in New Orleans, Louisiana. J natl cancer inst 41 (1968) 683-709.

6. Gardner MJ, Winter PD, Acheson ED. Variations in cancer mortality among local authority areas in England and Wales: Relations with environmental factors and search for causes. Br med j 284 (1982) 784787.

7. Howe GR, Burch JD, Miller AB, Cook GM. Esteve J, Morrison B, Gordon P, Chambers LW, Fodor G, Winsor GM. Tobacco use, occupation, coffee, various nutrients and bladder cancer. J natl cancer inst 64 (1980) 701-713.

8. Järvholm B, Lavenius B. A cohort study on cancer among workers exposed to an antirust oil. Scand $j$ work environ health 7 (1981) 179-184.

9. Järvholm B, Lillienberg L, Sallsten G, Thiringer G, Axelson O. Cancer morbidity among men exposed to oil mist in the metal industry. J occup med 23 (1981) 333-337.

10. Roush GC, Kelly J, Meigs JW, Flannery JT. Scrotal carcinoma in Connecticut metalworkers: Sequel to a study of sinonasal cancer. Am j epidemiol 116 (1982) 76-85.

11. Thony C, Thony J. Enquete epidemiologique sur le cancer des huiles de coup. Pre- 
sented at the 16th International Congress on Occupational Health and Occupational Cancer, Tokyo 1969.

12. Tola S, Tenho M, Korkala M-L, Järvinen E. Cancer of the urinary bladder in Finland. Int arch occup environ health 46 (1980) 4351.

13. Vineis $\mathrm{P}$. Industrial bladder cancer. $\mathrm{Br}$ med j 285 (1982) 295.

14. Wynder El, Goldsmith R. The epidemiology of bladder cancer: A second look. Cancer 40 (1977) 1246-1268. chemical technology. Interscience Publishers, New York, NY 1981.

Paolo Vineis, MD, Santa Di Prima, MD

Unit of Cancer Epidemiology

Main Hospital and University of Torino Istituto di Anatomia Patologica

via Santena 7

I-10126 Torino Italy 